\title{
APLIKASI STRUCTURAL EQUATION MODELLING (SEM) PADA KAJIAN PENGARUH KELEMBAGAAN: MODAL SOSIAL JIWA KEWIRAUSAHAAN TERHADAP KINERJA USAHA BUDIDAYA IKAN NILA KABUPATEN SLEMAN
}

\author{
Ratna Dewi Mulyaningtiyas \\ Pascasarjana Fakultas Pertanian, Universitas Gadjah Mada \\ Email: ratna_dm@yahoo.com \\ Irham, Masyhuri, dan Any Suryantini \\ Fakultas Pertanian Universitas Gadjah Mada
}

\begin{abstract}
Social capital becomes the main capital that must be owned by an entrepreneur, thus increasing the entrepreneurial spirit. The purpose of this research is to know the institutional condition of the members of the group of tilapia fish farm, the social capital of the member of the cultivation group of tilapia, the entrepreneurial spirit, farm performance of the tilapia fishery group, and the institutional influence, social capital, entrepreneurial spirit to the business performance of the nila fish farming group in Sleman District. The method used in this research is a method of a mixed method, with 150 responders and analyzed with SEM. The results showed that more than $50 \%$ of institutional conditions, social capital, entrepreneurial spirit, and business performance of tilapia fish farming group members of beginners, middle, and main in Ngemplak and Cangkringan Subdistrict Sleman Regency has a high category. There is no significant institutional influence on the influence of social capital on the entrepreneurial. Institutional is not a moderator variable between social capital relations and entrepreneurial spirit. This indicates that the higher/lower institutional will not result in changes the higher/lower the influence of social capital on entrepreneurial.
\end{abstract}

Keywords: Entrepreneurial Spirit; Farm Performance; Institutional; Social Capital; Structural Equation Modelling (SEM) Analysis.

\begin{abstract}
ABSTRAK
Modal sosial menjadi modal utama yang harus dimiliki oleh seorang wirausaha, sehingga meningkatkan jiwa kewirausahaan. Tujuan penelitian ini adalah untuk mengetahui kondisi kelembagaan, modal sosial, jiwa kewirausahaan, kinerja usaha anggota kelompok budidaya ikan nila, pengaruh kelembagaan, modal sosial, dan jiwa kewirausahaan terhadap kinerja usaha anggota kelompok budidaya ikan nila di Kabupaten Sleman. Metode yang digunakan dalam penelitian ini adalah metode mixed methods, dengan 150 respoden dan dianalisis dengan SEM. Hasil penelitian menunjukkan Lebih dari 50\% kondisi kelembagaan, modal sosial, jiwa kewirausahaan, dan kinerja usaha budidaya ikan nila anggota kelompok pemula, madya, dan utama di Kecamatan Ngemplak dan Cangkringan Kabupaten Sleman rata-rata memiliki kategori tinggi. Tidak terdapat pengaruh kelembagaan yang signifikan pada pengaruh modal sosial terhadap jiwa kewirausahaan. Kelembagaan bukan merupakan variabel moderator antara hubungan modal sosial dan jiwa kewirausahaan. Hal ini menunjukkan bahwa semakin tinggi/
\end{abstract}


rendahnya kelembagaan tidak akan mengakibatkan perubahan semakin tinggi/rendahnya pengaruh modal sosial terhadap jiwa kewirausahaan.

Kata Kunci: Analisis Structural Equation Modelling (SEM); Jiwa Kewirausahaan; Kelembagaan; Kinerja Usahatani; Modal Sosial.

\section{PENGANTAR}

Kewirausahaan budidaya ikan berperan untuk meningkatkan pendapatan masyarakat guna memenuhi kebutuhannya terutama kebutuhan dasar yang mencakup pangan, sandang, dan perumahan. Modal sosial secara tidak langsung berkaitan dengan sumber daya manusia.

Peran serta kelembagaan usaha pertanian diperlukan agar diperoleh hasil ekonomis yang lebih optimal sehingga dapat meningkatkan kinerja usahatani yang dilandasi dengan jiwa kewirausahaan. Provinsi Daerah Istimewa Yogyakarta (DIY) mempunyai lima kabupaten dan satu kota, Data perikanan tahun 2014 mencatat bahwa produksi perikanan mencapai $67.687,5$ ton atau naik sebesar 12,39 persen dibandingkan dengan tahun 2013 tercatat sebesar $60.226,6$ ton. Sekitar 95,98 persen dari total produksi perikanan merupakan hasil budidaya perikanan darat dan selebihnya 4,02 persen adalah hasil perikanan laut (BPS, 2014). Produksi terbesar perikanan darat berasal dari budidaya di kolam yang mencapai $62.238,32$ ton $(95,80$ persen). Nilai produksi perikanan sebesar Rp1.238,91 milyar, atau naik sebesar 53,58 persen dibanding tahun sebelumnya yang sebesar Rp806,7 milyar (BPS, 2014).

Selama kurun waktu tahun 2010 sampai 2015, ketersediaan ikan di Kabupaten Sleman semakin meningkat. Pada tahun 2010 ketersediaan ikan tercatat sebesar 26,73 kg/ kapita/th dan jumlahnya terus meningkat setiap tahunnya. Pada tahun 2015 ketersediaan ikan di Kabupaten Sleman menjadi 31,24 kg/ kapita/th, dengan rerata pertumbuhan yaitu $3,17 \mathrm{~kg} / \mathrm{kapita} / \mathrm{th}$. Dalam kurun waktu yang sama, produksi ikan konsumsi di Kabupaten Sleman pun juga meningkat. Pada tahun 2010 produksi ikan konsumsi sebanyak 14.574,680 ton dengan luasan kolam 629,13 ha, dan di tahun 2015 jumlah produksi ikan konsumsi tercatat sebesar 36.627,00 ton dengan luasan kolam 960,2 ha. Jadi rerata peningkatannya sebesar $16,67 \%$ setiap tahunnya untuk produksi ikan konsumsi dan luasan kolam.

Kelembagaan dapat menggambarkan pola perilaku dan hubungan suatu organisasi tertentu dalam hubungannya dengan lingkungan atau sumberdaya (Ruttan, 1984). Peran serta kelembagaan usaha pertanian diperlukan agar diperoleh hasil ekonomis yang lebih optimal sehingga dapat meningkatkan kinerja usahatani yang dilandasi dengan jiwa kewirausahaan. Dalam menjalankan suatu kewirausahaan, kelompok (pemula, madya, utama) mempunyai peranan penting dalam pengembangan usaha.

Kewirausahaan membutuhkan modal tertentu, tetapi tidak selalu berupa modal material yang memiliki wujud, tetapi juga modal yang tidak berbentuk yakni berupa modal sosial. Modal sosial menjadi modal utama yang harus dimiliki oleh seorang wirausaha, sehingga meningkatkan jiwa kewirausahaannya. Kerjasama yang ada di antara anggota kelompok membentuk sebuah jaringan interaksi tersendiri.

Dalam upaya untuk mengembangkan usaha budidaya ikan, maka dibutuhkan adanya modal. Dalam konteks sosial bahwa upaya pengembangan usaha kecil dibutuhkan adanya hubungan kerjasama dengan orang lain. Hubungan kerjasama ini disebut sebagai modal sosial.

Modal sosial (social capital) sebagai norma informal yang dapat mendorong kerjasama antar anggota masyarakat (Fukuyama, 1995 dalam Siregar, 2011). Modal sosial mengasumsikan sumber daya yang terdapat dalam salah satu hubungan sosial dapat digunakan untuk mendukung adanya kewirausahaan, yang diekspektasikan pada kepastian penjelasan yang lebih lengkap tentang fenomena, dan mengungkapkan tambahan wawasan untuk keberhasilan pembangunan kewirausahaan dalam konteks negara berkembang (Zhao dkk., 2011).

Modal sosial organisasi memliki andil yang besar dalam meningkatkan keunggual- 
an organisasi. Hal ini bisa terjadi karena secara struktural, relasional, dan kognitif, memampukan organisasi untuk memprediksikan perubahan yang terjadi di luar organisasi (Permadi, 2002).

Kelembagaan adalah aturan perilaku yang mengatur pola tindakan dan hubungan. Kelembagaan dapat menggambarkan pola perilaku dan hubungan suatu organisasi tertentu dalam hubungannya dengan lingkungan atau sumberdaya (Ruttan, 1984). Hira dan Hira (2000) menjelaskan perubahan kelembagaan dari perspektif yang berbeda. Pertama, perubahan kelembagan terjadi sebagai reaksi dari faktor ekonomi baru yang biasanya direfleksikan dengan adanya perubahan harga relatif dan selera. Kedua, wirausahawan (bisa individu maupun organisasi) yang terdapat dalam sebuah sistem kelembagaan ujungujungnya akan menghasilkan perubahan yang inovatif. Salah satu kegiatan berbudidaya yang telah berjalan dalam kelompok adalah budidaya ikan nila. Ikan nila merupakan salah satu komoditas yang cukup penting baik untuk jenis pembesaran maupun pembenihan, sedangkan untuk memenuhi kebutuhan konsumsi pasar lokal maupun luar kota masih sangat kurang, sehingga dengan melihat peluang maka ingin mencoba meningkatkan produksi ikan nila untuk pemenuhan kebutuhan ukuran konsumsi melalui kegiatan budidaya pembesaran ikan nila.

Berdasarkan latar belakang tersebut maka tujuan dalam penelitian ini adalah untuk mengetahui kondisi kelembagaan anggota kelompok budidaya ikan nila, modal sosial anggota kelompok budidaya ikan nila, jiwa kewirausahaan anggota kelompok budidaya ikan nila, serta pengaruh kelembagaan, modal sosial, jiwa kewirausahaan terhadap kinerja usaha anggota kelompok budidaya ikan nila di Kabupaten Sleman.

\section{Metode}

Penelitian ini dilakukan di Kabupaten Sleman, DIY. Lokasi penelitian ditentukan dengan metode purposive yaitu dengan memilih lokasi penelitian di Kecamatan Ngemplak dan Cangkringan Kabupaten Sleman berdasarkan pertimbangan bahwa di lokasi tersebut terdapat kelompok tani budidaya ikan yang sudah di kelompokkan berdasarkan peringkat kelompok (pemula, madya, utama). Metode pengambilan responden ditentukan dengan metode stratified random sampling yaitu suatu teknik pengambilan sampel dengan memperhatikan suatu tingkatan (strata) pada elemen populasi (pemula, madya, utama) dengan jumlah 150 responden. Metode dasar yang digunakan adalah mixed methods merupakan pendekatan penelitian yang mengkombinasikan atau mengasosiasikan bentuk kualitatif dan kuantitatif (Creswell, 2015). Analisis yang digunakan adalah SEM dengan bantuan Skala likert (Riduwan,2002).

\section{HASIL DAN PEMBAHASAN Kelembagaan Anggota Budidaya Ikan Nila}

Kelembagaan petani merupakan lembagalembaga yang anggotanya adalah petani dan berada dalam ikatan kerja sama untuk memenuhi kebutuhan bersama. Kelembagaan ini berbentuk kelompok tani. Hasil penelitian ini membahas berapa besar tingkat kelembagaan yang ada di Kecamatan Ngemplak dan Cangkringan.

Variabel Kelembagaan diukur oleh enam indikator antara lain kinerja anggota, kepemimpinan, iklim kelembagaan, motivasi, kedisiplinan, dan nilai kebudayaan. Distribusi frekuensi jawaban respon tiap item pertanyaan pada tiap indikator dan variabel secara lengkap disajikan pada tabel 1 .

Tabel 1

Deskripsi Frekuensi Variabel Kelembagaan

\begin{tabular}{l|l|l|l|l|l|l}
\hline \multirow{2}{*}{\multicolumn{1}{c|}{ Indikator }} & \multicolumn{5}{c|}{ Frekuensi Jawaban Responden (\%) } & \multirow{2}{*}{ Total } \\
\cline { 2 - 6 } & \multicolumn{1}{c|}{ STS } & \multicolumn{1}{c}{ TS } & \multicolumn{1}{c}{ RR } & \multicolumn{1}{c}{ SS } & \\
\hline Kinerja anggota & 0,00 & 16,00 & 32,67 & 32,67 & 18,67 & 100 \\
Kepemimpinan & 0,00 & 11,33 & 31,33 & 36,00 & 21,33 & 100 \\
\hline
\end{tabular}




\begin{tabular}{l|l|l|l|l|l|l}
\hline \multirow{2}{*}{\multicolumn{1}{c|}{ Indikator }} & \multicolumn{7}{c|}{ Frekuensi Jawaban Responden (\%) } & \multirow{2}{*}{ Total } \\
\cline { 2 - 7 } & \multicolumn{1}{c|}{ STS } & \multicolumn{1}{c|}{ TS } & \multicolumn{1}{c|}{ RR } & \multicolumn{1}{c}{ SS } & \\
\hline Iklim kelembagaan & 0,00 & 13,33 & 36,67 & 32,00 & 18,00 & 100 \\
Motivasi & 0,00 & 19,33 & 24,67 & 38,00 & 18,00 & 100 \\
Kedisiplinan & 0,00 & 18,67 & 32,67 & 29,33 & 19,33 & 100 \\
Nilai kebudayaan & 0,00 & 8,67 & 30,00 & 40,67 & 20,67 & 100 \\
\hline Rata-rata (\%) & 0 & 14,56 & 31,34 & 34,77 & 19,33 & \\
\hline
\end{tabular}

Sumber: Analisis Data Primer, 2017

Berdasarkantabel1rata-rata $54 \%$ menjawab setuju dan sangat setuju, hal ini berarti bahwa kelembagaan budidaya ikan nila berkembang baik. Hasil deskripsi variabel kelembagaan pada tabel 1 diperoleh sebagian besar distribusi jawaban responden $(n=150)$. Sebesar $61,34 \%$ indikator nilai kebudayaan memiliki nilai frekuensi tertinggi. Nilai kebudayaan dalam penelitian ini yaitu (1) adanya budaya tepat waktu antara anggota dengan kelompok; (2) nilai kesopanan dalam menjalin hubungan antar sesama anggota terjaga; (3) membantu dalam kegiatan berusahatani; dan (4) saling mengingatkan antar anggota kelompok. Menurut Soekanto (1993), kebudayaan merupakan bagian dari lingkungan yang diciptakan oleh manusia dimana dalam suatu masyarakat ada kebudayaan dan tingkah laku organisasi kelompok tani usaha budidaya ikan nila tersebut. Anggota kelompok tidak akan berkembang tanpa adanya kebudayaan yang mendasarinya.

\section{Modal Sosial Anggota Budidaya Ikan Nila}

Kegiatan dalam usaha budidaya usahatani, modal sosial berfungsi sebagai pengungkit berhasilnya kegiatan usaha karena modal sosial mengandung nilai-nilai kerjasama. Variabel Modal Sosial diukur berdasarkan enam indikator antara lain kepercayaan, partisipasi, norma, kekerabatan, jaringan sosial, dan gotong royong. Intepretasi hasil pengolahan data disajikan pada tabel 2.

Tabel 2

Deskripsi Variabel Modal Sosial Anggota Kelompok Budidaya Ikan Nila

\begin{tabular}{|c|c|c|c|c|c|c|}
\hline \multirow{2}{*}{ Indikator } & \multicolumn{5}{|c|}{ Frekuensi Jawaban Responden (\%) } & \multirow{2}{*}{ Total } \\
\hline & STS & TS & RR & S & SS & \\
\hline Kepercayaan & 0,00 & 18,67 & 30,00 & 32,00 & 19,33 & 100 \\
\hline Partisipasi & 0,00 & 13,33 & 34,67 & 40,67 & 11,33 & 100 \\
\hline Norma & 0,00 & 16,67 & 35,33 & 28,67 & 19,33 & 100 \\
\hline Kekerabatan & 0,00 & 18,67 & 31,33 & 30,00 & 20,00 & 100 \\
\hline Jaringan sosial & 0,00 & 17,33 & 32,67 & 37,33 & 12,67 & 100 \\
\hline Gotong royong & 0,00 & 13,33 & 34,67 & 37,33 & 14,67 & 100 \\
\hline Rata-rata (\%) & 0 & 16,33 & 33,11 & 34,33 & 16,22 & \\
\hline
\end{tabular}

Sumber: Analisis Data Primer, 2017

Berdasarkan tabel 2, rata-rata sebanyak $50,55 \%$ responden memberikan jawaban setuju dan sangat setuju pada variabel modal sosial di mana indikator keenam memiliki nilai rata-rata tertinggi yaitu gotong-royong dengan skor $(54 \%)$. Hal ini menunjukkan bahwa variabel Modal Sosial dipersepsikan dengan paling kuat oleh indikator gotongroyong dan dipersepsikan tinggi oleh responden. Modal sosial tingkatan tertinggi pada indikator gotong-royong karena gotongroyong merupakan local wisdom yang tetap melekat pada jiwa masyarakat di lokasi penelitian. Apalagi mereka tergabung dalam kelompok tani yang memiliki kesamaan nasib dan kesamaan tujuan. Meskipun mereka berwirausaha budidaya ikan nila karena sifat gotong-royong merupakan local wisdom yang 
tetap menjadi penciri khas maka mereka merasa bahwa berat harus sama dipikul ringan sama dijinjing. Aktivitas seseorang anggota dalam kelompok tani dengan gotong- royong tinggi akan mempengaruhi anggota yang lain.

Menurut Efendi (2013), Sebagai modal sosial, gotong royong dapat dijadikan rujukan dan pegangan dalam mencapai kemajuan suatu bangsa. Hal ini berarti bahwa masyarakat masih memegang teguh prinsip gotong-royong sebagai modal sosial. Nilai-nilai gotong royong dapat tumbuh dan berkembang menjadi energi sosial dalam memperkuat kohesi sosial melalui institusi-isntitusi lokal modal sosial.

\section{Jiwa Kewirausahaan Anggota Budidaya Ikan Nila}

Kewirausahaan adalah kemampuan kreatif dan indikatif yang dijadikan peluang menuju sukses (Suryana, 2004). Untuk dapat menjadi wirausaha yang berhasil, dibutuhkan jiwa kewirausahaan di antaranya adalah optimis (Y1), tanggung jawab (Y2), kerja keras (Y3), inovasi kreativitas (Y4), berani mengambil risiko (Y5), dan pengambilan keputusan (Y6). Distribusi frekuensi jawaban respon tiap item pertanyaan pada tiap indikator disajikan pada tabel 3.

Tabel 3

Deskripsi Variabel Jiwa Kewirausahaan Anggota Kelompok Budidaya Ikan Nila

\begin{tabular}{|c|c|c|c|c|c|c|}
\hline \multirow{2}{*}{ Indikator } & \multicolumn{5}{|c|}{ Frekuensi Jawaban Responden (\%) } & \multirow{2}{*}{ Total } \\
\hline & STS & TS & RR & $\mathrm{S}$ & SS & \\
\hline Optimis & 0,00 & 19,33 & 29,33 & 34,67 & 16,67 & 100 \\
\hline Tanggung jawab & 0,00 & 14,67 & 34,67 & 37,33 & 13,33 & 100 \\
\hline Kerja keras & 0,00 & 14,67 & 34,67 & 34,00 & 16,67 & 100 \\
\hline Inovasi kreativitas & 0,00 & 10,67 & 34,67 & 40,00 & 14,67 & 100 \\
\hline Pengambilan risiko & 0,00 & 14,67 & 38,67 & 28,67 & 18,00 & 100 \\
\hline Pengambilan keputusan & 0,00 & 10,00 & 31,33 & 42,67 & 16,00 & 100 \\
\hline Rata-rata (\%) & - & 14,00 & 13,89 & 36,22 & 15,89 & \\
\hline
\end{tabular}

Sumber: Analisis Data Primer, 2017

Berdasarkan tabel 3, sebanyak 52,11\% responden memberikan jawaban Setuju dan Sangat Setuju. Hal ini berarti kondisi jiwa kewirausahaan tergolong bagus karena memiliki nilai frekuensi lebih dari 50\% yaitu $52,11 \%$. Indikator keenam merupakan indikator yang memiliki nilai frekuensi paling tinggi yaitu pengambilan keputusan sehingga variabel jiwa kewirausahaan paling kuat diukur oleh indikator pengambilan keputusan, maka dapat dikatakan bahwa jiwa kewirausahaan dipersepsikan tinggi oleh responden. Hal ini didukung juga oleh Kao (2001) yang menyatakan perusahaan kecil yang ingin berkembang harus memiliki semangat kewirausahaan. Selain itu, Gray (2002) mempertegas bahwa dengan semangat kewirausahaan yang dimiliki, para pemilik usaha kecil dapat mengungguli pesaingpesaingnya. Georgellis et al., (2000) menyatakan, kapasitas mereka untuk berinovasi dan keberanian mengambil risiko menjadikan usaha dapat berkembang dengan sukses.

Konstruk Kewirausahaan dicerminkan oleh optimis, tanggung jawab, kerja keras, inovasi kreativitas, berani mengambil risiko, pengambilan keputusan menunjukkan hubungan yang kuat (nilai estimate $>0,5$ Artinya optimis, tanggung jawab, kerja keras, inovasi kreativitas, berani mengambil risiko, dan pengambilan keputusan dapat menjelaskan keberadaan konstruk dari kewirausahaan. Menurut Nitisusastro (2009) indikator dari variabel jiwa kewirausahaan yaitu motivasi, inovasi, dan risiko. Indikator tersebut sama dengan penelitian yang telah dilakukan oleh Noersasongko (2005).

\section{Kinerja Usahatani Anggota Budidaya Ikan Nila}

Kinerja usahatani merupakan hasil kegiatan usahatani. Oleh karena kinerja 
usahatani merupakan variabel yang tidak dapat diukur langsung, maka dalam penelitian ini kinerja usahatani diukur oleh tiga indikator antara lain pendapatan, keuntungan, dan kelayakan usaha. Distribusi frekuensi jawaban respon tiap item pertanyaan pada tiap indikator dan variabel disajikan pada tabel 4 .

Tabel 4

Deskripsi Variabel Kinerja Usahatani

\begin{tabular}{|c|c|c|c|c|c|c|}
\hline \multirow{2}{*}{ Indikator } & \multicolumn{5}{|c|}{ Frekuensi Jawaban Responden (\%) } & \multirow{2}{*}{ Total } \\
\hline & STS & TS & RR & S & SS & \\
\hline Pendapatan & 0,00 & 0,00 & 16,00 & 33,33 & 35,33 & 100 \\
\hline Keuntungan & 0,00 & 0,00 & 19,33 & 27,33 & 38,67 & 100 \\
\hline Kelayakan & 0,00 & 0,00 & 20,00 & 26,67 & 32,67 & 100 \\
\hline Rata-rata $(\%)$ & 0 & 0 & 18,44 & 29,11 & 35,56 & \\
\hline
\end{tabular}

Sumber: Data diolah, 2017

Berdasarkan tabel 4, diketahui bahwa sebanyak 54,67 \% responden menjawab Setuju dan Sangat Setuju. Kondisi kinerja usahatani secara umum sudah bagus. Adapun konstruk kinerja usahatani dicerminkan oleh pendapatan, keuntungan, dan kelayakan (Y15). Indikator kedua merupakan indikator yang memiliki nilai frekuensi paling tinggi yaitu keuntungan sehingga variabel kinerja usahatani paling kuat diukur oleh indikator keuntungan, maka dapat dikatakan bahwa kinerja usahatani dipersepsikan tinggi oleh responden.

\section{Pengaruh Kelembagaan, Modal Sosial Jiwa Kewirausahaan terhadap Kinerja Usaha Budidaya Ikan Nila}

Modal sosial menurut Fukuyama (2014) adalah rangkaian nilai-nilai atau norma-norma informal yang dimiliki bersama di antara para anggota suatu kelompok masyarakat yang memungkinkan terjalinnya kerjasama di antara mereka. Adapun kelembagaan berkaitan dengan organisasi yang terbentuk atas dasar keinginan bersama masyarakat dalam rangka mencapai tujuan tertentu. pencapaian target kelembagaan yang sesuai dengan keinginan kelompok dan tujuan bersama masyarakat, maka dibutuhkan kerjasama, kepercayaan, gotong royong, jaringan serta sikap yang akan melahirkan perilaku kewirausahaan di antara anggotanya.

Modal sosial secara tidak langsung berkaitan dengan sumber daya manusia.
Berbagai sifat dan karakter manusia dapat menentukan keberlangsungan kelembagaan atau organisasi sosial tertentu, termasuk didalamnya kelompok tani. Terdapatnya sumber daya manusia yang berkualitas, tujuan dari kelembagaan akan mudah terealisasikan serta akan lebih berhasil dan berdaya. Sikap saling menghargai, mempercayai, mampu berkejasama dengan siapapun dan gotong-royong memiliki pengaruh besar terhadap perkembangan jiwa dan perilaku kewirausahaan seperti meningkatnya kepercayaan masyarakat yang dimanifestasikan dalam perilaku jujur, teratur, dan bekerjasama berdasarkan norma-norma yang dianut bersama. Dengan demikian, modal sosial tidak hanya memiliki peran penting dalam kelembagaan, tetapi mampu mempengaruhi perilaku kewirausahaan.

Kewirausahaan membutuhkan modal tertentu, tetapi tidak selalu berupa modal material yang memiliki wujud, tetapi modal sosial yaitu modal yang tak berbentuk. Modal sosial menjadi modal utama yang harus dimiliki oleh seorang wirausaha, sehingga meningkatkan jiwa kewirausahaannya. Modal sosial menurut Suryana (2014) mencakup sikapsikap di antaranya kejujuran, kepercayaan (trust), dan komitmen. Sikap tersebut berperan sebagai modal utama mampu meningkatkan citra. Modal sosial sangat diperlukan dalam usaha tani karena banyak sekali aktivitas usaha tani yang memerlukan kebersamaan dalam kelompok. Pada pemasaran komoditas 
pertanian, modal sosial juga diperlukan karena komoditi pertanian kualitasnya bersifat mudah rusak, sehingga menimbulkan kecurangan dalam transaksi apalagi tidak seiring dengan adanya modal sosial. Oleh karena itu, diperlukan kelembagaan dengan mengutamakan modal sosial berupa sikap dan perilaku yang sesuai dengan nilai dan norma yang dibentuk atas dasar kesepakatan bersama, sehingga mampu meningkatkan jiwa kewirausahaan. Crijns dan Ooghi (2000) menjelaskan bahwa setiap tahap pertumbuhan perusahaan merupakan hasil dari dua lingkungan di mana perusahaan melakukan bisnisnya, yaitu lingkungan internal dan eksternal.
Nilai loading factor (untuk indikator refleksif) dan loading factor (untuk indikator reflektif) menunjukkan bobot dari setiap indikator sebagai pengukur dari masingmasing variabel laten. Indikator dengan loading factor/weight terbesar menunjukkan bahwa indikator tersebut sebagai pengukur variabel yang terkuat (dominan). Konstruk model yang disajikan merupakan model yang dihasilkan dengan memiliki kesesuaian model (goodness of fit) selanjutnya nilai-nilai indeks akan dibandingkan dengan nilai kritis (cut off value) dari masing-masing indeks. Adapun model yang dihasilkan disajikan dalam gambar 1 .

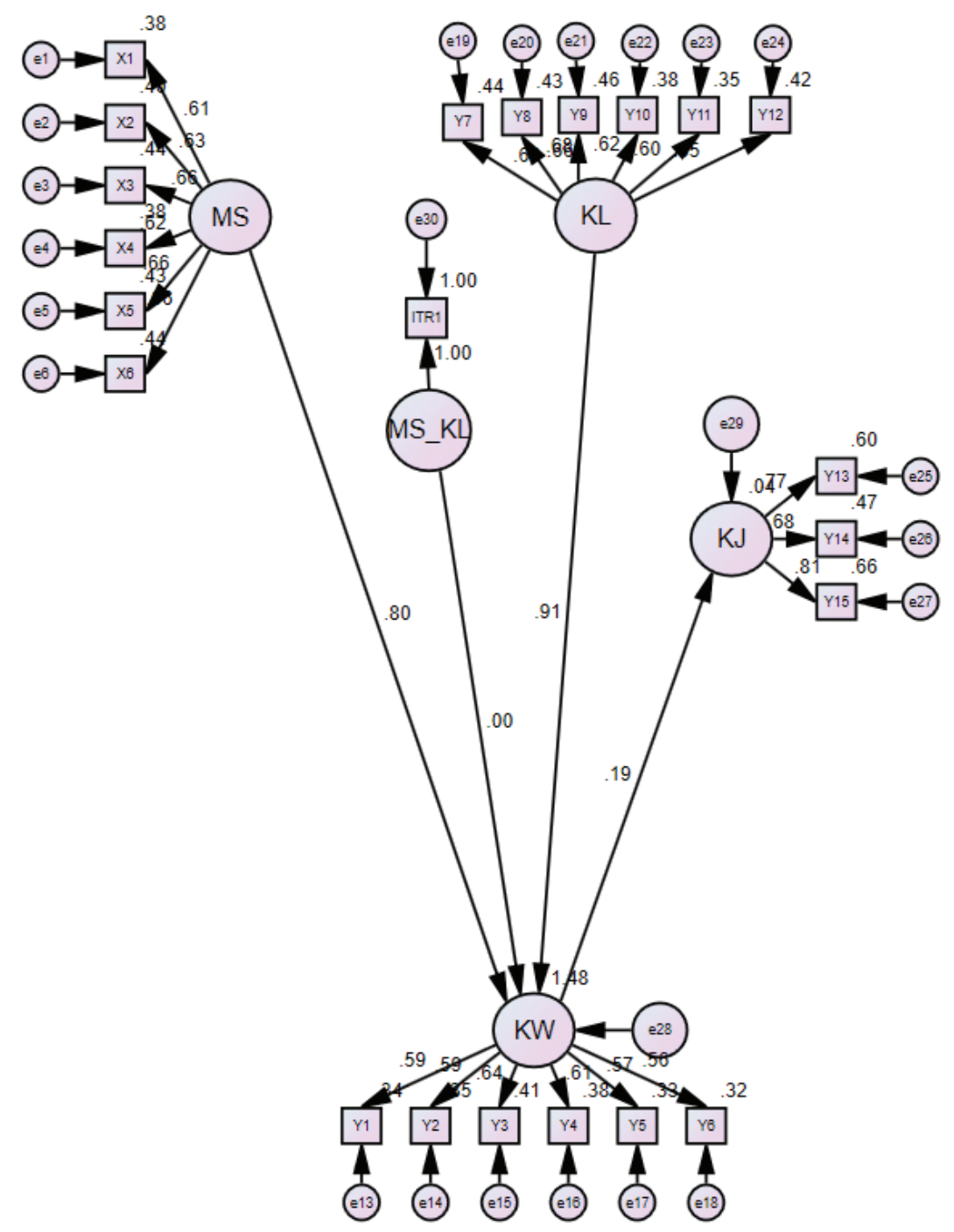

Gambar 1.

Model Model Pengaruh Kelembagaan, Modal sosial, Kewirausahaan terhadap Kinerja Usahatani 
Modal sosial dicerminkan oleh kepercayaan, partisipasi, norma, kekerabatan, jaringan sosial, gotong-royong. Konstruk Kewirausahaan dicerminkan oleh optimis, tanggungjawab, kerja keras, inovasi kreativitas, berani mengambil risiko, dan pengambilan keputusan. Konstruk Kelembagaan dicerminkan oleh kinerja kelembagaan, kepemimpinan, iklim kelembagaan, motivasi, kedisiplinan, dan nilai kebudayaan. Hasil pengujian Goodness of Fit Overall memperlihatkan bahwa dari 5 (lima) kriteria yaitu Khi Kuadrat, p-value, CMIN/DF, TLI, CFI, dan RMSEA menunjukkan model yang baik. Sedangkan, GFI dan AGFI menunjukkan model marginal. Menurut Arbuckle dan Wothke (dalam Solimun, 2009), kriteria terbaik yang digunakan sebagai indikasi kebaikan model adalah nilai p-value lebih dari 0.05, Chi Square/DF kurang dari 2, GFI lebih dari 0.90, AGFI lebih dari 0.90, TLI lebih dari 0.95, CFI lebih dari 0.95, dan RMSEA kurang dari 0.08. Pada penelitian ini, nilai CMIN/DF dan RMSEA telah memenuhi nilai cut off. Oleh karena itu, model SEM pada penelitian ini cocok dan layak untuk digunakan, sehingga dapat dilakukan interpretasi guna pembahahasan lebih lanjut. Nilai estimate dampak moderasi kelembagaan pada pengaruh modal sosial terhadap jiwa kewirausahaan budidaya ikan nila disajikan pada tabel 5 .

Tabel 5

Nilai estimate dan signifikansi pengaruh variabel

\begin{tabular}{lllll}
\hline \multicolumn{1}{c}{ Keterangan } & Estimasi & S.E & C.R & \multicolumn{1}{c}{ P } \\
\hline KW <--- MS & .663 & .117 & 5.681 & $* * *$ \\
KW <--- MS_KL & -.047 & .032 & 1.466 & -.143 \\
KW <--- KL & .739 & .125 & 5.906 & $* * *$ \\
X6 <--- MS & 1.000 & & & \\
X5 <--- MS & .947 & .167 & 5.680 & $* * *$ \\
X4 <--- MS & 1.105 & .187 & 5.924 & $* * *$ \\
X3 <--- MS & 1.191 & .188 & 6.335 & $* * *$ \\
X2 <--- MS & .842 & .154 & 5.472 & $* * *$ \\
X1 <--- MS & 1.025 & .182 & 5.644 & $* * *$ \\
Y7 <--- KL & 1.000 & & & \\
Y8 <--- KL & .986 & .150 & 6.555 & $* * *$ \\
Y9 <--- KL & .969 & .150 & 6.483 & $* * *$ \\
Y10<--- KL & .938 & .154 & 6.079 & $* * *$ \\
Y11<--- KL & .975 & .157 & 6.207 & $* * *$ \\
Y12<--- KL & .805 & .135 & 5.940 & $* * *$
\end{tabular}

\begin{tabular}{|c|c|c|c|c|}
\hline Keterangan & Estimasi & S.E & C.R & $\mathrm{P}$ \\
\hline $\mathrm{Y} 13<---\mathrm{KJ}$ & 1.000 & & & \\
\hline Y14 <--- KJ & 0.907 & .123 & 7.371 & $* * *$ \\
\hline Y15 <--- KJ & 1.163 & .149 & 7.802 & $* * *$ \\
\hline Y6 <--- KW & 1.000 & & & \\
\hline Y5 <--- KW & 1.360 & .226 & 6.017 & $* * *$ \\
\hline Y4 <--- KW & 1.158 & .197 & 5.868 & $* * *$ \\
\hline Y3 <--- KW & 1.284 & .217 & 5.924 & $* * *$ \\
\hline Y2 <--- KW & 1.121 & .196 & 5.705 & $* * *$ \\
\hline Y1 <--- KW & 1.254 & .218 & 5.757 & $* * *$ \\
\hline ITR1<--- KW & 1.000 & & & \\
\hline
\end{tabular}

Sumber: Analisis data primer, 2017

Dengan melihat $p$-value yang dihasilkan (kolom P) berupa tiga buah asterik $\left({ }^{* * *}\right)$ yang berarti nilainya sangat kecil $(<0,001)$ (Dachlan, 2014), dengan demikian jika tanda yang ditampilkan maka parameter populasi secara signifikan nol. Pada perhitungan ini bahwa dari ketiga hipotesis, yaitu 2 (dua) ditolak dan 1 (satu) diterima. Dapat ditarik kesimpulan bahwa pengaruh modal sosial (H1) dan pengaruh kelembagaan (H3) secara signifikan berpengaruh posistif terhadap jiwa kewirausahaan. Sedangkan interaksi modal sosial dan kelembagaan tidak berpengaruh terhadap jiwa kewirausahaan (H2). Aspek positif dari pengaruh tersebut adalah dengan melihat koefisien regresi maupun nilai thitung (C.R) yang nilainya positif untuk $\mathrm{H} 1$ dan $\mathrm{H} 3$, sedangkan $\mathrm{H} 2$ nilainya negatif. Karena $P$ value untuk $\mathrm{H} 1$ dan $\mathrm{H} 3$ nilainya sangat kecil $\left({ }^{* * *}\right)$,kedua hipotesis nol tersebut ditolak dan H2 lebih dari nol maka diterima.

Berdasarkan tabel 5 diketahui bahwa konstruk modal sosial dicerminkan oleh kepercayaan (X1) memiliki nilai estimate 1,025, partisipasi (X2) dengan nilai estimate 0,842 , jaringan sosial (X3) memiliki nilai estimate 1,191, kekerabatan (X4) memiliki nilai estimate 1,105, norma (X5) memiliki nilai estimate 0,947, gotong-royong (X6) memiliki nilai estimate 1,000, dan semua indikator signifikan pada taraf 5\% artinya bahwa kepercayaan, partisipasi, jaringan sosial, kekerabatan, norma, gotong-royong dapat menjelaskan keberadaan konstruk modal sosial. 
Konstruk kelembagaan dicerminkan oleh: kinerja kelembagaan (Y7) dengan nilai estimate 1,000, kepemimpinan (Y8) dengan nilai estimate 0,986, iklim kelembagaan (Y9) dengan nilai estimate 0,969 , motivasi (Y10) dengan nilai estimate 0,938 , kedisiplinan (Y11) dengan nilai estimate 0,975, dan nilai kebudayaan (Y12) dengan nilai estimate 0,805 , artinya bahwa kinerja kelembagaan, kepemimpinan, iklim kelembagaan, motivasi, kedisiplinan, dan nilai kebudayaan dapat menjelaskan konstruk kelembagaan.

Konstrukjiwa kewirausahaan dicerminkan sebagai berikut: optimis (Y1) dengan nilai estimate 1,254, tanggungjawab (Y2) dengan nilai estimate 1,121, kerja keras (Y3) dengan nilai estimate 1,284, inovasi kreativitas (Y4) dengan nilai estimate 1,158 , berani mengambil risiko (Y5) dengan nilai estimate 1,360, pengambilan keputusan (Y6) dengan nilai estimate 1,000 yang artinya bahwa optimis, tanggungjawab, kerja keras, inovasi kreativitas, berani mengambil risiko, dan pengambilan keputusan dapat menjelaskan konstruk jiwa kewirausahaan.

Konstruk Kinerja Usahatani dicerminkan oleh keuntungan, pendapatan, kelayakan menunjukkan hubungan yang kuat (nilai estimate > 0,5). Keuntungan (Y13) memiliki nilai estimate 0,771 , pendapatan (Y14) memiliki nilai estimate 0,68 , dan kelayakan usaha (Y15) memiliki nilai estimate 0,81. Artinya pendapatan, keuntungan, dan kelayakan usaha dapat menjelaskan keberadaan konstruk kinerja usahatani. Menurut Ferdinand (2002) dan Kusnendi (2007), suatu indikator dinyatakan valid jika nilai estimasi koefisien bobot faktor yang distandarkannya (standardized factor loading) tidak kurang dari 0,40.

Pengaruh langsung antara modal sosial terhadap jiwa kewirausahaan, diperoleh nilai koefisien inner loading sebesar 0,663 dengan $p$-value sebesar $<0.001$. Oleh karena itu, $p$-value $<0.05$, maka terdapat pengaruh langsung yang signifikan 5\% antara Modal Sosial terhadap Jiwa Kewirausahaan. Mengingat koefisien inner loading bertanda positif mengindikasikan bahwa hubungan keduanya positif. Artinya, semakin tinggi Modal Sosial akan mengakibatkan semakin tinggi Jiwa Kewirausahaan. Sejalan dengan hasil penelitian pengembangan modal sosial secara optimal dapat dilakukan bila manajer atau pengusaha berorientasi entrepreneur dengan orientasi entrepreneur yang kuat akan memerlukan sumber daya jaringan yang berbeda dibandingkan usaha yang lebih konservatif untuk mencapai kinerja yang unggul. Posisi jaringan industri dan ikatanikatan penghubung akan meningkatkan kinerja perusahaan (Stam et al., 2006).

Pengujian pengaruh langsung antara kelembagaan terhadap jiwa kewirausahaan, diperoleh nilai koefisien inner loading sebesar 0.739 , dengan $p$-value sebesar $<0.001$. Karena $p$-value $<0.05$, maka terdapat pengaruh langsung yang signifikan 5\% antara Kelembagaan terhadap Jiwa Kewirausahaan. Mengingat koefisien inner loading bertanda positif, mengindikasikan bahwa hubungan keduanya positif. Artinya, semakin tinggi kelembagaan akan mengakibatkan semakin tinggi jiwa kewirausahaan. Sejalan dengan penelitian Sadikin et al., (2009) dalam mengembangkan usahatani kelembagaan dari pihak pemerintah maupun lembaga swadaya diperlukan dalam mendukung keberhasilan petani.

Pada pengujian pengaruh interaksi (moderasi) modal sosial dan kelembagaan terhadap Jiwa Kewirausahaan, diperoleh koefisien inner loading sebesar -0.047 dengan $p$-value sebesar 0.143. Karena p-value $>0.05$, sehingga Ha ditolak. Kondisi kelembagaan petani saat ini lebih bersifat budaya (local wisdom) dan sebagian besar berorientasi hanya untuk mendapatkan fasilitas pemerintah, belum sepenuhnya diarahkan untuk memanfaatkan peluang bisnis melalui pemanfaatan aksesibilitas terhadap berbagai informasi teknologi, permodalan dan pasar yang diperlukan bagi pengembangan usahatani. Kelembagaan tidak memperkuat pengaruh modal sosial terhadap jiwa kewirausahaan. Hasil dilapangan menunjukkan bahwa nilai rata-rata kinerja kelembagaan, modal sosial, dan jiwa kewirausahaan dalam kategori tinggi. Kelembagaan memiliki dasar kepentingan, sifat, kesamaan perilaku yang berdasar pada karakter sosial yang disebut sebagai social relationship contohnya kegiatan gotong-royong, 
sedangkan kewirausahaan berorientasi pada bisnis (business oriented) yang mengutamakan keuntungan di atas hubungan sosial.

Hal ini sejalan dengan penelian Fauzan (2002) yang mengemukakan bahwa gaya kepemimpinan transformasional tidak memoderasi hubungan dimensi struktural modal sosial dan kinerja tugas dosen. Berbeda dengan penelitian yang dilakukan Lee et al., dalam Nugroho et al., (2015) pada industri terkemuka di Taiwan dan penelitian lanjutan Stam et al., (2014) pada industri software open source Belanda menempatkan modal sosial sebagai variabel yang memoderasi hubungan antara orientasi entrepreneur dengan kinerja perusahaan. Hasil penelitian keduanya menunjukkan modal sosial yang tinggi akan memperkuat hubungan antara orientasi entrepreneur dengan kinerja. Kombinasi sentralitas jaringan yang tinggi dan ikatan-ikatan penghubung yang ekstensif memperkuat hubungan diantara orientasi entrepreneur dengan kinerja.

\section{SIMPULAN}

Lebih dari 50\% kondisi kelembagaan, modal sosial, jiwa kewirausahaan, dan kinerja usaha budidaya ikan nila anggota kelompok pemula, madya, dan utama di Kecamatan Ngemplak dan Cangkringan Kabupaten Sleman tergolong tinggi. Selain itu ternyata tidak terdapat pengaruh kelembagaan yang signifikan pada pengaruh modal sosial terhadap jiwa kewirausahaan. Kelembagaan bukan merupakan variabel moderator antara hubungan modal sosial dan jiwa kewirausahaan. Hal ini menunjukkan bahwa semakin tinggi/rendahnya kelembagaan, tidak akan mengakibatkan perubahan semakin tinggi/ rendahnya pengaruh modal sosial terhadap jiwa kewirausahaan

\section{DAFTAR PUSTAKA}

BPS. 2014. Tabel Dinamis Produksi Ikan Darat menurut Jenis Budidaya dan Kabupaten/Kota di D.I. Yogyakarta (Ton). Diakses pada tanggal 21 Maret 2018.<https://yogyakarta.bps. go.id/site/resultTab>.
Creswell, J. W. 2015. Research Design Pendekatan Kualitatif, Kuantitatif, dan Mixed. Yogyakarta: Pustaka Pelajar.

Crijns, H. dan Ooghi. 2000, Growth Paths of Medium Sized Entrepreneurial Companies. De Vlerick School Voor Management, University of Ghent.

Dachlan, U. 2014. Panduan Lengkap Structural Equation Modeling-Tingkat Dasar. Semarang: Lentera Ilmu.

Efendi, T. 2013. Reformasi Birokrasi dan Iklim Investasi. Jakarta: Konpress.

Fauzan, M. 2002. Peningkatan Kinerja Dosen Berbasis Modal Sosial dan Dukungan Organisasional di PTS Kota Semarang. Jurnal Bisnis dan Ekonomi (JBE). 19(2): 188 - 202.

Ferdinand, A. 2002. Structural Equation Modelling dalam Penelitian Manajemen. Semarang: Badan Penerbit UNDIP.

Fukuyama, F. 2014. The Great Distruption. Yogyakarta: Qalam.

Georgellis, Y., Joyce, P. dan Woods, A. 2000. "Entrepreneurial Action, Innovation, and Business Performance : The Small Independent Business". Journal of Small Business and Enterprise Development 7(1): 7-17.

Gray, C. 2002. "Entrepreneurship Resistance to Change and Growth in Small Firms". Emerald Journal of Small Business and Enterprise Development 9(1).

Hira, A dan R. Hira. 2000. The Institutionalism: Contradictory Notions of Change. American. Journal of Economics and Sociology. 59(2): 267-282.

Kao, J. 2001. Entrepreneurship, Creativity, and Organization. New Jersey: Prentice Hal.

Kusnendi. 2007. Model-model Persamaan Struktural. Bandung: Alfabeta.

Nitisusastro, M. 2009. Kewirausahaan dan Manajemen Usaha Kecil. Jakarta: Alfabeta. 
Noersasongko, E. 2005. Analisis Pengaruh Karakteristik Individu, Kewirausahaan dan Gaya Kepemimpinan Terhadap Kemampuan Usaha Serta Keberhasilan Usaha Pada Usaha Kecil Batik di Jawa Tengah. Skripsi. Malang: Program Pascasarjana Universitas Merdeka Malang.

Nugroho, S. P., dan Setyawan, A.A. 2015. Pemoderasian Modal Sosial pada pengaruh Orientasi Entrepreneur terhadap Peningkatan Kinerja Organisasi (studi empiris pada UKM di Kota Surakarta). BENEFIT Jurnal Manajemen dan Bisnis. 19(1): 80-94.

Permadi, D. C. 2002. Analisis Pengaruh Modal Sosial Organisasi dan Modal Intelektual Organisasi terhadap Keunggulan Organisasi. Tesis, Bogor: Magister Manajemen IPB.

Riduwan, 2002. Skala Pengukuran VariabelVariabel Penelitian. Jawa Barat: IKAPI.

Ruttan, V. W. 1984. Models of Agricultural Development, dalam C.K. Eicher\& J.M.Staatz (eds). Agriculture Development in The Third World. London: The John Hopkins University Press.

Sadikin, I., A. Djauhari dan B. Hutabarat. 1999. Kajian Kelembagaan Agribisnis Dalam Mendukung Pengembangan
Sistem Usaha Pertanian Bebasis Agroekosistem. Bogor: Pusat Penelitian dan Pengembangan Sosial Ekonomi Pertanian Balitbang Pertanian.

Siregar. 2011. Modal Sosial Para Pedagang Kaki Lima Etnis Jawa Studi di Daerah Nagoya Kota Batam. Jurnal Fisip UMRAH. 1(1): 93-106

Solimun. 2009. Permodelan Persamaan Struktural Berbasis SEM. Malang: UM Press Malang.

Stam,W., S. Arzlanian, dan T. Elfring. 2014. Social capital of Entrepreneurs and small firm perfomance: A metaanalysis of contextual and methodological moderators. Journal of Business Venturing. 29: 152-173.

Soekanto, S. 2005. Sosiologi Suatu Pengantar. Jakarta: Raja Grafindo Persada.

Suryana. 2014. Memahami Karakteristik Kewirausahaan. Modul, Jakarta: Depdiknas.

Zhao, Y. 2012. Measuring the Social Capital of Laid-off Chinese Workers. Current Sociology, 50(4): 555-71.

Zhao, W.B., J.R., R. Brent, and M.E. Charlotte. 2011. Social Capital and Tourism Entrepreneurship. Annals of Tourism Research J. 38(4): 1570-1593. 